\title{
The Educational Orientation of Boundary Communities at Sanggau Regency West Kalimantan
}

\author{
Kristianus ${ }^{1}$, Magdalena ${ }^{2}$ \\ ${ }^{1,2}$ Pontianak State Catholic College, West Kalimantan, Indonesia \\ ${ }^{1}$ kristianusatok@gmail.com, ${ }^{2}$ magdalenalina55@gmail.com
}

\begin{abstract}
Keywords:

Education, Dayak, Border Society, Future Orientation

The background of this research is the condition of Indonesia-Malaysia Border Society in Entikong Sub-district and Balai essay whose life is influenced by the border atmosphere. A day they interact with Malaysians. The author wants to know how to orientation the border to education. Using qualitative and quantitative combined methods, with 3 months ' research period, the author finds the following results: (1) There is a paradox situation between hope and the reality of education shown in the border area. The findings are not adequate aspects of education, ranging from sarana-prasarana, learning facilities, preparedness, the completeness of textbooks, and so on. (2) The orientation of community education in the frontier that successful authors find is (a) the orientation of the department, (b) Working orientation in Malaysia. (c) Orientation learning for living capital. (d) The results of this study show that most of the family's heads do not have their children who are 13-18 years old because they have to take their child to the city, while they have no family in the city to ride. (3) Education seems to evolve in the last 10 years, especially at the basic level (SD, SLTP, SLTA) because of the government's educational Assistance program.
\end{abstract}

\section{A. INTRODUCTION}

Society and culture greatly determines the orientation, nature or character of a person, because the life orientation of a person in his life is strongly influenced by these two factors, in addition to the family factor. In the border area between countries factors that are also strong influence on the orientation of a person's life is the aura or frontier atmosphere. This frontier atmosphere we refer to as a border culture. This border culture is formed because the community in its daily life always interact with the conditions of two countries at once. In their wallets there are always two currencies that are Rupiah and Ringgit. Their mobile phones generally consist of Indonesian phones such as TELKOMSEL and Malaysia phones such as Digi. The televisions they watch are also so. Kitchen needs are generally very nuanced Malaysian. This condition is very different from society that is far from the border. Of course, this condition affects the orientation of the Catholic family in terms of education.

General education in West Kalimantan province is not evenly distributed in all districts. Mainly inland districts and borders. Generally the inland district is the dominant Dayak 
population. Compulsory (natural) Program of nine years basic education in West Kalimantan until the beginning of 2018 New year reached 79.18 percent. Junior high school spread and lack of teachers to be a factor in the cause of the nine-year fair achievement in Kalbar has not been able to meet the national target of 95 percent in 2018. If referring to a national target, there are still about 16 percent of ELEMENTARY school graduates who need to be encouraged to continue their schooling to JUNIOR level.

The problem has not been in fact the distribution of SMP in Kalbar, being one of the factors causing the unachieving target. In some areas, especially in the inland and borders, students still have to travel long hours to proceed to junior secondary education. In order to overcome this issue, Kalbar will build 80-90 Junior high School buildings in 2018. The previous year Kalbar had built 58 SMP.

On the other hand, Kalbar was also still involved in a shortage of about 22,000 teachers, as well as about 2,000 classrooms that were in a broken state. The problem of illiteracy among the productive age (15-44 years) in Kalbar is also still a concern. Although the data of the office of the Kalbar Education in the beginning of 2018 shows the blind numbers range from 124,000 people, but the Central Statistics agency Kalbar noted that the blind figures in the area still ranged from 300,000 inhabitants. In this case, Kalbar ranks 23 out of 33 provinces in Indonesia and most of Kalimantan Island.

Conventional educational change to digital seems to grow rapidly nowadays. However, if it is being taken to the Indonesian border, it seems that massive digital education is conducted in the metropolis and the surrounding area is not yet valid. Entikong is one of the areas in Sanggau Regency, West Kalimantan-which is directly bordered by Malaysia. No wonder if the border line between Indonesia-Malaysia that is located in Entikong is called as a silk route because the bus from Indonesia-Malaysia or vice versa can enter two countries without having to spread the ocean. This silk path on one side has a positive and negative impact for the Entikong community. Education is one of the highlights that Governments should pay attention to in terms of service to students, the availability of educators, and learning facilities.

As reported by a number of media, West Kalimantan still need at least 15 thousand teachers to meet the minimum needs of Educators (Tribune Pontianak, 2017). There are at least 70 thousand teachers in West Kalimantan which are divided into 45 thousand civil servants and 25 thousand honorary teachers. Nonetheless, the availability of educators ' energies does not seem to spread evenly. Just as some schools in Entikong, Sanggau, West Kalimantan, had a silk path, it was unprofitable in education. SMK Yayasan Cross Border, MTs Istiqomah, and MI Istiqomah who settled in Entikong experienced the same suffering in terms of educators.

These schools are desperately looking for teachers who can fill certain subjects. The school was forced to take teachers from outside schools who had been entrusted with certain schools. The alternatives they use are to make teachers from other schools a flying teacher to fill in certain subjects. This issue may be resolved by the presence of a frontline teacher (GGD) program stationed at the Frontline School (SGD). The frontline school includes schools on location 3 T (outermost, leading, and lagging). Program SGD and GGD is the embodiment of the 3rd Nawacita program that builds from the periphery by strengthening areas and villages within the framework of the unitary State.

Based on the target of the 2016 last year, there were as many as 114 SGD which targeted with 11 new school units (7 SMA, 2 SMK, and 2 SLB) and 103 revitalization (27 SD, 30 SMP, 25 SMA, 18 SMK, 3 SLB) (Windows Education and culture, 2017). One of the areas that received attention about SGD and GGD is Sanggau, West Kalimantan. From the number of GGD registries 
in West Kalimantan, there are at least 1492 teachers for Sanggau, Bengkayang, and Sambas. The number of applicants is much more than the number of applicants in 48 other districts/cities.

The presence of GGD programs in the 3T area should be able to become an alternative to teacher equality. In addition, there must be advocacy of prospective youth other educators from the area concerned. Consequently if the distribution of teachers in the 3T area can not be solved, the students will not even get their full right to learn because there is no effectiveness in school learning. In Entikong's Hamlet, Sanggau, West Kalimantan was a student who was forced to not receive lessons in school hours because the teachers were not signed in or were not the availability of the teacher's forgiving subjects. Not infrequently I find SMK YLB's students out of class, playing ball, hanging out in front of the class, or Bolos. Perhaps, these students are tired of facing such a school condition.

\section{B. METHODS}

This research was conducted in the region of Entikong and Sekayam Sanggau district. This research uses a combined method of qualitative and quantitative research (sugiyono, 2010). The use of such methods is to consider the depth and sharpness of the data to be analyzed. This research covers the research of libraries and field research. The research begins with the collection of secondary data by conducting research libraries conducted in libraries, research centers or places that store books, articles, academic writings, research reports and so on that are relevant to the research.

As a qualitative study, the main instrument in this research is self-author. It contains the meaning that as a qualitative researcher the author must do field work directly to collect data with observation methods and interviews. By conducting an involved observation (Participant observation, or ethnographic fieldwork) which is the foundation of cultural anthropology, means using the data collection techniques that are central to the ethnographic process (Randa et al., 2011).

Ethnographic methods are defined as observations involved "a research "strategy that simultaneously combines document analysis, interviewing of respondents and informants, direct participation and observation, and introspection". In this process known as "self-immersion" (immersion) in order to get the data emic SI researchers entered into the way of life, how to speak, how to apply, and how to think the society that it is studied.

In-depth interviews are first addressed specifically to the "key informant" of the education leaders of the current frontier (Moleong, 2007). This way, their thoughts, focus attention, and their activities can be explored in detail. Life history techniques will be used to track back the history and personal experiences of members and the elite of Dayak community at the border (Salako, Bidayuh, Iban). In-depth interviews were also addressed to the second informant who may not have experienced it but got a story from previous figures. Observations were conducted to observe the equipment used in daily life and also in their traditions. Interviews were conducted to acquire data relating to educational elements and life orientations.

Quantitative methods are conducted using questionnaires (Sugiyono, 2011). Questionnaires were created in two forms: open questions and closed questions. Open-ended questions are meant to give respondents the answers to their opinions and abilities. This open-ended question is aimed at teachers, community leaders and Catholic Church leaders. While a closed question is made by making the preferred answer $(a, b, c, d, e)$. This closed question is given to respondents and students. 


\section{RESULT AND DISCUSSION}

\section{Educational conditions at the border}

Education is a conscious and well-planned endeavor to create a learning atmosphere and learning process so that students actively develop their potential to possess the spiritual power of religion, self-control, personality, intelligence, noble morality, and skills necessary to himself and society. Education includes teaching special skills, as well as something that cannot be seen but more deeply, namely the giving of knowledge, consideration and wisdom. One of the main bases of education is to teach culture through generations.

The author finds a paradoxical situation between the hopes and realities shown by the border area. One of them in the education sector, the findings are not adequate aspects of education, ranging from learning facilities, employment, the completeness of textbooks, and so on. The development of education in the border area is also very related to the need to develop and form the students ' national insight, attitudes, and behaviour. Various phenomena indicate still low awareness and attitude of the national insight.

Therefore, optimizing the education of the border area is something that needs to be examined seriously, in depth, and careful. It is not excessive if the research centre for the Balitbang policy-KEMENDIKBUD in 2012 directs one of its studies to the issues of education in the border area. Through the study came the conclusion that the border needs a touch of quality education in order to improve the quality of its human resources. This research findings also showed that there has been no significant changes since 2012 until now concerning the advancement of education in the border area. Although through the improvement of the quality of human resources, it is expected to be an entrance to improve the level and welfare of people in the border area with high and national character.

On that basis to produce education in the border area that is quality, obviously needed attention and analysis to all subsystems or components of the education, including the students ' condition, facilities of infrastructure, laboran, education costs, curriculum, and learning outcomes. Please be aware that the conditions of the existing components of this research are still very limited. Even the influence of the less component to the student learning outcomes on the influential border is not good.

One thing that needs to be underlined, that the condition and situation of the education in the Malaysian area that borders the Entikong is very good. The respondent said that the situation in our region is still very consigned and faced with various constraints and limitations. Respondents said that efforts to produce quality human resources in border areas should pay more attention to the issue of education development.

Other research findings that the communities of border areas, especially school children, its orientation is heavily influenced by the stimulation of neighboring countries. Respondents said the school in Indonesia could not print jobs, unlike in Malaysia. It is not only related to the urge to follow the offer of schooling in neighboring countries, but also the tendency to not continue education (drops out) by finding jobs in neighboring countries. The waiver on the subject of educational development will only lead to a good hope of forming and developing quality human resources in the border areas, and it is difficult to expect the role and function of the border areas as a leading guard to prevent and ward off all distractions, innuisance, and outside threats.

Respondents had the view that their school was heavily influenced by the cost of education incurred, especially if it would proceed to college. If for SD-SMA so far has been 
got help from the government. A parent's spending on child education costs, becomes great when going to college.

In a number of places directly adjacent to the neighboring country of Malaysia, it is interesting that they do not question these costs. According to the number of parents interviewed, if they are struggling to run a school in the country, they will be approached to school schools in the neighboring country who are willing to accept their children. It is said that the neighboring country schools are not only free, but also have facilities of infrastructure, learning facilities, and others that are better than the schools in Indonesia. Even when the weekend breaks, the school provides pocket money and transportation funds for Indonesian children who will return to their homes.

The second perceived respondents influence the outcomes of the teacher, among others, including the importance of providing facilities to teachers to perform the learning tasks, the completeness of the number of educational and non-educators, dedication and integrity of educators and non-educators to perform tasks in the border area, as well as the welfare level. Further, the curriculum (K-2013) is perceived by respondents in the third place, primarily referring to the importance of teachers ' efforts to actively search for enrichment books in carrying out learning assignments, improving skills, knowledge, and skills continuously, and utilizing handbook/packages provided by the Government.

\section{Orientation of population education in border area}

Based on the authors' findings, the authors:

\section{a. Position Orientation}

The border society is also still the view that the higher the level of education will be the higher positions and occupations that one has. They see this evidence can be from the recruitment pattern of civil servants (PNS) that the higher the certificate of graduation of an employee, in question will occupy a higher class as well. Therefore, the opportunity to occupy office or work related to responsibility and authority will be possessed by those who are educated.

In line with the era of regional autonomy and the implementation of decentralized education, districts and cities have their own duties and authorities to plan and advance the field of education (Soapatty, 2014). The right and authority for the district in education turned out to be insufficient. The school has so far been free to manage education. This approach system is called the School Based Management System, which is the school organizes education according to the needs and interests of the educational community (school stakeholders). Through this concept of school management and community management, parents are expected to participate actively in the management of education. But the findings of this research indicate that they have not been involved in school management.

\section{b. Working orientation in Malaysia.}

The interviews can be noted that parents say "their children are important to work in Malaysia. The author also knows that over $90 \%$ of families have family members working in Malaysia. The parents ' opinion in the border region is aligned with the issue of Link and Match (Mahdum et al., 2014). Explained in the issue there is a connection between education and labor problems. The often questioned, namely the association and the match between the world of education and work. This problem is backed by the more well-known education capital that has the labor not always in accordance with the field of work done. Even in employment there is a missmatch between education graduates with 
the needs of the business world. It is further said that there is a problem between employment and the educational background that is owned by a person. But the community, including the parents, is still hoping for the institution to produce a skilled and knowledgeable child who can eventually obtain a suitable job field (Kristianus, 2017).

\section{c. Orientation Learning for Living capital.}

Data based on interviews with respondents, strong indications that their opinions are influenced by their experience while still alive in Malaysia. They had the view that the school was essentially learning to be alive (Ab Halim \& Nur Hanani, 2017). It is not undeniable in the present era of formal education that is usually pursued in schools can get also outside school. School that I mean is the school in general. As for the outside school because there is no denying that certain parents who were to have the children in the House of his term is "home schooling".

The school teaches us a new world that teaches us to socialize with others who are of course new and unfamiliar. Therefore, the first day in school is usually embraced by the cry of the new child. Schools educate us to dig science so that every human being can achieve goals in his life or more precisely what is coveted and dream from small or also at least become human as most people are in school. The school is a place that provides human opportunities to be more useful for the nation and the country or at least useful for the family because the higher a human school is certainly the opportunity to get a better job. The school also educates people to humanize others, teaches people to understand and love others besides themselves because in schools of course we will meet people with different attitudes and traits.

\section{d. Education orientation Mimics Malaysia}

The findings of this research are the economic background of the community in the border area is generally still low. In fact, socio-economic background of the community can influence the low level of education participation (Lyndon et al., 2012). The social background certainly does not run on its own to affect education, but there are several other factors that contribute to it. Another factor in the achievement of education is such as the availability of good education system and management and the availability of infrastructure and geographical conditions that support (Yu, 2008). However, it may often be considered as a factor of perception and desire for people who are closely related to the values and characteristics of the community (Coenders \& Scheepers, 2003) .

The community life in the research area (district of Entikong and Sekayam subdistrict, Sanggau Regency) is based on the agriculture sector. Rice paddy field is quite spacious, which is by people planted with rice and crops (Fox \& Atok, 1997). Farmer communities generally live depending on the cultivation of land, but not all residents in this area control enough land. Based on the results of interviews with locals it is known that all people are working on their own land or family owned. But there are also a handful of migrants who become farm laborers.

The social life factor of society here is backed by its livelihood which is much dependent on farmland. However, agricultural land and yard land around the house have been narrowed because of the process of population growth in a natural or migration. The process of population development naturally, for example, is the marriage event of the inhabitants who give offspring. The older generation of residents will lower the inheritance, both home and land, and paddy fields. In fact, the area of the land must be divided into offspring so that each child has a large area of land that is not so great. The 
narrowness of land ownership resulted in limited employment opportunities and income from agricultural processing. The increasing population pressures have also not been balanced with job developments, especially outside the agricultural sector.

Another impact is the need to find alternative employment alternatives outside of land work. This not only means the difficulty of finding a livelihood, but also weakens the ability of the family's socio-economic life. The difficulty of the domestic economy is an aspect that needs to be searched immediately and therefore, the work must be created and searched immediately. In fact, agricultural land is the most accessible job seeker by job seekers, but the complexity of the land causes the workday to be not maximal.

\section{Parents ' expectations of education and children's work}

On this occasion the questions posed to parents are related to their expectations of the child's education and the work in fact is expected. This question does not apply to children who are in school, but for those who are not in school anymore. The result in general is that the work they are doing is now not in accordance with expectations.

Child is a family asset and all children in Indonesia are the assets of the nation. They need to gain opportunities to grow and thrive. But not all children are able to grow and develop through educational means (Diyah Lusiana, 2017). They are generally hampered by poverty and problems in the family. Even many children who leave the school bench to work cover the economic needs. Although educational facilities and infrastructure are available, education will not achieve the expected outcome if the community is poorly responded to. Habits do not want to be able to blame the child can happen to the isolated village community. Decades ago there were still many villagers who still thought that working on land was an opportunity to meet the shortage of labor. But the habit has gradually shifted to consider that education is the object of life of children in the future (Ardi et al., 2007).

As already mentioned first, human resources investment theory states that there is a positive relationship between education (level and field) with economic progress in a country or region (Atmanti, 2005). Economic problems are closely related to job issues. An education investment in practice requires a huge fee and a long time. It is reasonable when people expect maximum results also for the education of their children. Therefore, to discuss the expectations of children's education and also job expectations, it is also necessary to talk about the availability of educational facilities and background of public in general (Slameto, 2003).

According to many group discussion participants, the condition of education in these two sub-districts is running towards development. They were inspired by the educational advances in Malaysia. From interviews with many parties it seems that the community is beginning to realize the importance of education in people's lives, as stated by a local community figure that education will make it easier for someone to get a job. It seems that opinion is supported by some who follow the discussion. Education is considered by some parents to be able to improve the fate of his children so that unlike his parents who are still stupid. The views of the local community will of course be stimulants or boosters to understand the importance of education. Education is also considered important for his children to reach the future and a good thing for the environment. A positive understanding of education is certainly a community driver to participate in school. This condition can be proved by increasing the number of purely educational participation in Sanggau Regency. 
There has been a shift in public view in the research area when compared to the situation 10 years ago. A former Hamlet chief states that the school needs a big fee, but the parents have a land that is wide enough to be cultivated so that children should be employed on the farm. This statement shows that the child is a valuable labor resource in the family to work on the land. Agriculture culture presumably causes community thinking patterns to be simple and just thought of working for today alone (Darmadi, 2017). Investing or thinking far forward has not been implied in their minds at that time. has stated that in rural families, the welfare factors of home are influential in the field of education.

The results showed that most of the family heads did not school their children aged 1318 years because the cost of education was considered expensive and not affordable to them. A total of 62.7 percent of the 59 heads of families who had such age children did not. But there was also another answer stating that his child's ability to learn had diminished and they wanted his son to work quickly. The picture shows that the cost of education is still considered too expensive. Therefore, the policy to alleviate costs or eliminate the altogether tuition fees for elementary school is an appropriate policy. This policy is intended to further encourage increased school participation. On the other, the now widely available educational facilities are relatively close to the residents ' settlements. The current education facility has been better than 10 years ago which is still limited.

Education seems to evolve in the last 10 years, especially at the basic level (SD, SLTP, SLTA) because of the government's educational Assistance program. Even the assistance was not only to public schools, but also private schools. In a hope there is also a goal or desire that a person wants to achieve. If asked, generally parents (50 percent) expect to be able to school their children to scholars. Some respondents (16.3 percent) also interest in vocational high schools. This picture of course indicates that not everyone in the area wants to school their children to a higher level of education. From this it appears that the public also does not dream too far, but measures the expectation with their abilities. What is interesting is that almost nobody hopes to only be able to get their children to SMP level. This reinforces the assumption that high school is the minimum education level a child should go to if they want to enter the job field.

Education that has been lived by children aged 6 to 12 years in the research village. Shows that in general they graduate in elementary school. The educational condition that has been pursued by those who are not in school shows a declining percentage. This means the higher the level of education, the more unfollowed by most children in the research area. The participation of education in previous years is still not noticeable, at least it happened about 10 years ago. If compared to the expectations of parents and the fact that there is, there appears to be reversed comparisons. Parents hope that his children achieve undergraduate education is 49.9 percent, but apparently there is nothing at all that reaches the undergraduate level. Instead, 50 percent of children who are not continuing to pursue education are those who are only elementary school education.

Then the parents who hoped to have their children at the level of general education in secondary school were 16 percent, but in fact only lived by about 5 percent or as a citizen of what parents expected. The same number of respondents expects their children to attend public schools and vocational schools, although the percentage for vocational schools is slightly larger. This possibility is due to the wishes of those attending a vocational school to directly enter the job market and do not want to continue the school again. 
Poverty issues are important to address as poverty will demonstrate the hellessness of society in all aspects of life. Poverty will affect the poor level of health and education. Poverty will also affect the unsuccess of a program or government policy. Therefore, poverty is an aspect that must be considered and performed to achieve a prosperous society in accordance with the goals of the nation and state.

Poverty may affect people's perception and attitude toward educational expectations. Increasingly a poor categorized village, it is estimated that there is no desire for parents to be able to. This is because the child can be considered as the production factor of the buffer economic life. Poor villages are indicated by the number of beneficiaries of BLT which is relatively much. The larger the population receives the BLT, the village is a poor village group. Questions related to parents ' expectations of education are any differences in expectations between those who accept help and who are not.

The other question is a link between the ethnic groups and the expectation of education because of education. As it is known that education is critical to future life, but other ethnic groups may have different views on the importance of education. They could think that education was the burden of the family. Therefore, the dimension of poverty and ethnicity used to see the difference in parents ' expectations of education will give an interesting picture.

Generally respondents wanted his children to reach a degree in undergraduate education (43.6 percent for families who gained assistance and 60.3 percent were not). This picture shows that a better economic society shows greater hope for his child to be a scholar compared to those who belong to the recipient family. But the recipient community also shows the greatest percentage in terms of her children's hope of being a bachelor. For the secondary education level, people who gained greater assistance in public schools $(22$ percent) compared with 7.9 percent of those who did not get help. For the level of the academy, it seems that the percentage of those who did not obtain a lower aid (14.9 percent) compared to a society that did not receive BLT (20.2 percent). If further observed, the number of people.

Based on the results of the survey conducted during the study, the orientation of Dayak people to become civil servants is the largest (33.5 percent), followed by being a teacher (29.9 percent) and doctors (12.4 percent). Malay people who want to become civil servants are 62.7 percent, teachers of 13.7, and members of ABRI 19.6, while expecting their children to be only 1 percent doctor. For the people of Java and other entrants in the area, their greatest hope is to become self-employed (29.4 percent), who want to be ABRI 17.6 percent, become a doctor 23.5 percent, and become a civil servant almost 12 percent. Based on the data, it is known that the position as a member of civil servants, ABRI and POLRI, doctors, and teachers is still the biggest expectation of society in the research village. If generally stated, the conclusion is actually the general public, both from the immigrants, Dayak and Malay, still hopes great that his child can be a civil servant of any kind of work. Only a slight shift for the Javanese people in the overseas because it seems to work as an entrepreneur who became an idol. But this hope has not been fully true because the basic education is not yet adequate in addition to the many obstacles, such as the limitation of employment opportunities in some areas. 


\section{CONCLUSION AND SUGGESTIONS}

The author finds a paradoxical situation between the hopes and reality of education shown in the frontier area. The findings are not adequate aspects of education, ranging from saranaprasarana, learning facilities, preparedness, the completeness of textbooks, and so on. The development of education in the border area is also very related to the need to develop and form the students ' national insight, attitudes, and behaviour. Various phenomena indicate still low awareness and attitude of the national insight. Respondents had the view that interest in the child's education was 6-12 years old and is influenced by the cost of tuition, because so far it has received government assistance. Parental expenditure on child education costs is relatively small. In a number of places directly adjacent to neighboring Malaysia, the child does not question this cost. According to the number of parents interviewed, when they are struggling to run a school in the country, it will be to school in a neighboring country that is willing to accept their child. It is said that the neighboring country schools are not only free, but also have saranaprasarana, learning facilities, and others that are better than the schools in Indonesia. Even when the weekend breaks, the school provides pocket money and transportation funds for Indonesian children who will return to their homes.

Orientation of the population education in the frontier that the successful authors find is (1) The orientation of the department, where they view that the higher the level of education will be higher and the position and work that someone has. They see this evidence can be from the recruitment pattern of civil servants (PNS) that the higher the certificate of graduation of an employee, in question will occupy a higher class as well. Therefore, the opportunity to occupy office or work related to responsibility and authority will be possessed by those who are educated. 2 Working orientation in Malaysia. The interviews can be noted that parents say "their children are important to work in Malaysia. The author also knows that over $90 \%$ of families have family members working in Malaysia. (3) Orientation learning for living capital. Data based on interviews with respondents, strong indications that their opinions are influenced by their experience while still alive in Malaysia. They had the view that the school was essentially learning to be alive. (4) Orientation of education and poverty relations. According to many group discussion participants, the educational conditions in this area are underway towards development. People begin to realize the importance of education in people's lives, as stated by a local community figure that education will make it easier for a person to get a job. It seems that opinion is supported by some who follow the discussion. Education is considered by some parents to be able to improve the fate of his children so that unlike his parents who are still stupid. The views of the local community will of course be stimulants or boosters to understand the importance of education. Education is also regarded as an important thing for his children to reach the future and a good thing for his environment. A positive understanding of education is certainly a community driver to participate in school. This condition can be proved by increasing the number of purely educational participation in Sanggau Regency.

The results of this study show that most of the family's heads do not have their children who are 13-18 years old because they have to take their child to the city, while they have no family in town to ride. They assume tuition fees to higher tiers are expensive and unreachable for them. A total of 62.7 percent of the 59 heads of families who had such age children did not. But there was also another answer stating that his child's ability to learn had diminished and they wanted his son to work quickly. Therefore, the policy to alleviate costs or to completely eliminate the cost of education for junior high school and high school is the proper policy. This policy can further 
encourage increased school participation. On the other, the current education facility has been better than 10 years ago which is still limited.

Education seems to develop in the last 10 years, especially at the basic level (SD, SLTP, SLTA) because of the government's educational Assistance program. Even the assistance was not only to public schools, but also private schools. Parents (50 percent) are expected to be able to school their children until their scholars. Some respondents (16.3 percent) also interest in vocational high schools. This picture of course indicates that not everyone in the area wants to school their children to a higher level of education. From this it appears that the public also does not dream too far, but measures the expectation with their abilities. What is interesting is that almost nobody hopes to only be able to get their children to SMP level. This reinforces the assumption that high school is a minimum education level that children must go to if they want to enter employment.

Education that has been lived by children aged 6 to 12 years in the research village. Shows that in general they graduate in elementary school. The educational condition that has been pursued by those who are not in school shows a declining percentage. This means the higher the level of education, the more unfollowed by most children in the research area. The participation of education in previous years is still not noticeable, at least it happened about 10 years ago. If compared to the expectations of parents and the fact that there is, there appears to be reversed comparisons. Parents hope that his children achieve undergraduate education is 49.9 percent, but apparently there is nothing at all that reaches the undergraduate level. Instead, 50 percent of children who are not continuing to pursue education are those who are only elementary school education.

Then the parents who hoped to have their children at the level of general education in secondary school were 16 percent, but in fact only lived by about 5 percent or as a citizen of what parents expected. The same number of respondents expects their children to attend public schools and vocational schools, although the percentage for vocational schools is slightly larger. This possibility is due to the wishes of those attending a vocational school to directly enter the job market and do not want to continue the school again.

It appears that the hope of the Dayak community to become a civil servant is the largest (33.5 percent), followed by being a teacher (29.9 percent) and doctors (12.4 percent). Malay people who want to become civil servants are 62.7 percent, teachers of 13.7 , and members of ABRI 19.6, while expecting their children to be only 1 percent doctor. For the people of Java and other entrants in the area, their greatest hope is to become self-employed (29.4 percent), who want to be ABRI 17.6 percent, become a doctor 23.5 percent, and become a civil servant almost 12 percent. Based on the data, it is known that the position as a member of civil servants, ABRI and Polri, doctors, and teachers is still the biggest expectation of society in the research village. If generally stated, the conclusion is actually the general public, both from the immigrants, Dayak and Malay, still hopes great that his child can be a civil servant of any kind of work. Only a slight shift for the Javanese people in the overseas because it seems to work as an entrepreneur who became an idol. But this hope has not been fully true because the basic education is not yet adequate in addition to the many obstacles, such as the limitation of employment opportunities in some areas.

\section{ACKNOWLEDGEMENT}

The title for the thank you to the institution or the person who has contributed during the research and references is not numbered. 


\section{REFERENCES}

A’ing, A. (2015). Studi Tentang Pembangunan Bidang Pendidikan di Daerah Perbatasan Kecamatan Kayan Hulu Kabupaten Malinau. Pemerintahan Integratif.

Ab Halim, T., \& Nur Hanani, H. (2017). Pendidikan Abad ke 21 Dalam Kepelbagaian Budaya : Cabaran dan Harapan. Kertas Kerja Ucap Utama Seminar Pedagogi Antarabangsa Ke-8 (PEDA8) Anjuran IPG Ilmu Khas, Kuala Lumpur, Universitas Pendidikan Indonesia, Bandung Dan Kolej Universiti Islam Antarabangsa Selangor Pada 19 September 2017 Di Institut Pendidikan Guru Kampus Il.

Ardi, S., Syed, B., Kamal, Y., Madya, P., \& Tasir, Z. (2007). Pembelajaran masa depan - mobile learning (mlearning) di malaysia. Pembelajaran Masa Depan - Mobile Learning (m-Learning) Di Malaysia.

Atmanti, D. H. (2005). Investasi sumber daya manusia melalui pendidikan. Jurnal Dinamika Pembangunan (JDP).

Coenders, M., \& Scheepers, P. (2003). The effect of education on nationalism and ethnic exclusionism: An international comparison. Political Psychology, 24(2), 313-343. https://doi.org/10.1111/0162895X.00330

Darmadi, H. (2017). Dayak and Their Daily Life. JETL (Journal Of Education, Teaching and Learning). https://doi.org/10.26737/jetl.v2i1.145

Diyah Lusiana, W. L. (2017). Journal of Educational Research and Evaluation. Jurnal of Educational and Evaluation.

Fox, J., \& Atok, K. (1997). Forest-dweller demographics in West Kalimantan, Indonesia. Environmental Conservation, 24(1). https://doi.org/10.1017/S0376892997000076

Gloria A. Tangkeallo, Rijanto Purbojo, \& Kartika S. Sitorus. (2014). Hubungan Antara Self-Efficacy Dengan Orientasi Masa Depan Mahasiswa Tingkat Akhir. Jurnal Psikologi UIN Sultan Syarif Kasim Riau.

Husna, A. N. (2015). Orientasi Hidup Materialistis dan Kesejahteraan Psikologis. Seminar Psikologi \& Kemanusiaan.

KBBI. (2016). Kamus Besar Bahasa Indonesia ( KBBI ). In Kementerian Pendidikan dan Budaya.

Kristianus. (2017a). Dialektika Budaya Dayak: Inkulturasi Agama Katolik dengan Budaya Dayak Kayaan. Juli Jurnal Studi Kultural, 2 85-91. https://www.academia.edu/33620056/Dialektika_Budaya_Dayak_Inkulturasi_Agama_Katolik_deng an_Budaya_Dayak_Kayaan

Kristianus, K. (2017b). The Development of Multicultural Education Model in West Kalimantan. JETL (Journal Of Education, Teaching and Learning). https://doi.org/10.26737/jetl.v2i1.144

Lyndon, N., Selvadurai, S., Mat Jali, M. F., Awang Besar, J., Rosniza Aznie, C. R., Ali, M. N. S., \& Abd Rahim, M. H. (2012). Pendidikan dan komuniti Bidayuh: Kajian kes perbezaan gender dalam penyertaan dan pencapaian. Geografia: Malaysian Journal of Society and Space, 8(8), 170-179.

Mahdum, Wan Hasmah Wan Mamat, \& Zulfahmi. (2014). Pendidikan holistik tantangan dan masa depan. Pendidikan Holistik Tantangan Dan Masa Depan.

Moleong. (2007). Meode penelitian. Landasan Teori. https://doi.org/10.1017/CB09781107415324.004

Mukminan. (2015). Kurikulum Masa Depan. Seminar Dan Kuliah Tamu.

Nurrohmatulloh, M. A. (2016). Hubungan Orientasi Masa Depan dan Dukungan Orang Tua Dengan Minat Melanjutkan Studi ke Perguruan Tinggi. EJournal Psikologi.

Pemerataan Kesempatan Memperoleh Pendidikan Tingkat SLTP di Daerah Perbatasan Kalbar-Malaysia. (2004). Jurnal Penelitian Dan Evaluasi Pendidikan. https://doi.org/10.21831/pep.v1i1.2108

Randa, F., Triyuwono, I., Ludigdo, U., \& Sukoharsono, E. A. (2011). Studi etnografi: akuntabilitas spiritual pada organisasi gereja katolik yang terinkulturasi budaya lokal. In Jurnal Akuntansi Multiparadigma (Vol. 2, Issue 1, pp. 35-51).

Sarwono, S. W. (2011). Psikologi Remaja Edisi Revisi. In Psikologi Remaja. https://doi.org/10.1108/09513551011032482.Bastian

Slameto. (2003). Prestasi Belajar. Journal of Education. https://doi.org/10.1016/j.jfineco.2008.10.007

Soapatty, L. (2014). Pengaruh Sistem Sekolah Sehari Penuh (Full Day School) Terhadap Prestasi Akademik Siswa Smp Jati Agung Sidoarjo. E-Journal UNESA.

sugiyono. (2010). Metode Penelitian Kuantitatif \& kualitatif. In Journal of Experimental Psychology: General.

Sugiyono. (2011). Metode Penelitian Kuantitatif, kualitatif dan R \& D. Bandung: Alfabeta, 90. https://doi.org/10.1017/CB09781107415324.004

Sumber Daya Manusia dan Produktivitas Kerja. (2016). Istinbath.

Yu, W. (2008). Globalization and cultural identity. In Globalization and Education (pp. 159-165). https://doi.org/10.1515/9783110207019 